\title{
Deterioration and mortality among patients with United Network for Organ Sharing status 2 heart disease: Caution must be exercised in diverting organs
}

Nahush A. Mokadam, MD, ${ }^{a}$ Gregory A. Ewald, MD, ${ }^{\text {b }}$ Ralph J. Damiano, Jr, MD, and Nader Moazami, MD, ${ }^{a}$ St Louis, Mo

See related editorial on page 775 .

$\mathrm{T}$

The initial thoracic organ allocation scheme was 7-tiered, based on that used for renal allocations. The first revision, in 1989, was to a 2-tiered system. Because of its inadequacy in addressing certain patients and potential for abuse, and before widespread use of ventricular assist devices, the United Network for Organ Sharing (UNOS) in 1999 modified its thoracic organ allocation scheme from a 2-tiered to a 3-tiered system. ${ }^{1}$

As contemporary medical and nontransplant surgical therapy for heart failure continues to improve, the benefit of heart transplantation in patients with UNOS status 2 heart disease has come under scrutiny. Recently, UNOS proposed a modification for the heart transplant allocation scheme that increases availability of hearts to patients with status $1 \mathrm{~A}$ and $1 \mathrm{~B}$ heart disease (Table 1). ${ }^{2}$ This study sought to evaluate the outcome of UNOS status 2 registrants in the era of modern medical management and under the current UNOS scheme for heart transplantation.

\section{Materials and Methods}

The study cohort included all patients aged more than 18 years who were added to the UNOS/Organ Procurement and Transplantation Network (OPTN) registry between January 1, 2001, and December 31, 2003. Demographic and clinical information were

From the Divisions of Cardiothoracic Surgery ${ }^{\mathrm{a}}$ and Cardiology, ${ }^{\mathrm{b}}$ Washington University School of Medicine, St Louis, Mo.

United Network for Organ Sharing/Organ Procurement and Transplantation Network data retrieval was supported in part by Health Resources and Services Administration contract 231-00-0115. The content is the responsibility of the authors alone and does not necessarily reflect the views or policies of the Department of Health and Human Services, nor does mention of trade names, commercial products, or organizations imply endorsement by the US Government.

Presented at the American Transplant Congress, Seattle, Wash, May 22, 2005.

Received for publication May 13, 2005; accepted for publication Aug 17, 2005.

Address for reprints: Nader Moazami, MD, Washington University School of Medicine, Department of Surgery, Division of Cardiothoracic Surgery, Queeny Tower-Suite 3108, One Barnes-Jewish Hospital Plaza, St Louis, MO 63110 (E-mail:moazamin@msnotes.wustl.edu).

J Thorac Cardiovasc Surg 2006;131:925-6

$0022-5223 / \$ 32.00$

Copyright (C) 2006 by The American Association for Thoracic Surgery doi:10.1016/j.jtcvs.2005.08.022 collated by year, UNOS status at listing, and UNOS status at removal. Data obtained included age, diagnosis, change in status, removal from the waiting list for any reason, and waiting list duration. Events of interest included transplantation, upgrade in status to $1 \mathrm{~A}$ or $1 \mathrm{~B}$, removal from the waiting list for any reason, and death.

\section{Results}

From 2001 to 2003, there were 5467 heart transplantations performed in the United States. During this same time period, there were 1484 patients awaiting transplantation who died. There were 4184 new UNOS status 2 registrants during the study period. The average age was 51.4 years. Diagnoses were ischemic cardiomyopathy $(42.4 \%)$, followed by idiopathic cardiomyopathy $(30.5 \%)$, coronary artery disease $(4.8 \%)$, congenital heart disease $(3.8 \%)$, valvular heart disease $(3.0 \%)$, and all others $(15.3 \%)$.

Improvement leading to removal from the UNOS registry occurred in 176 patients (4.2\%). Median waiting list time was 406 days. A total of 1265 patients $(30.2 \%)$ required an upgrade to status $1 \mathrm{~A}$ or $1 \mathrm{~B}$. There were 85 patients $(2.0 \%)$ whose status was changed to "too sick to transplant" or "medically unsuitable." While waiting for transplantation, 426 patients (10.2\%) died (Table 2). The average number of days on the waiting list before death was 152 .

\section{Discussion}

The transplant community's generalized impression is that patients listed as UNOS status 2 remain stable for a prolonged period of time. With advances in modern medical therapy, including neurohormonal modulation and defibrillator/biventricular pacer therapy, the survival benefit of heart transplantation has been investigated. Patients listed as UNOS status 2 who are treated medically have 1-year survival comparable to those who undergo transplantation. ${ }^{3}$ The survival benefit from heart transplantation seems limited to those patients with the highest risk of dying, and perhaps restriction of transplantation to the sickest patients would improve posttransplant survival. ${ }^{4}$ It has been proposed that patients listed as UNOS status 2 may not derive benefit from transplantation unless an upgrade in status occurs, as in one study, 1-year survival in patients listed as status 2 was equivalent for those undergoing transplantation versus those remaining on the waiting list. ${ }^{3}$

Patients listed as UNOS status 2 represent a heterogenous group, some of whom will likely benefit from early transplantation rather than after clinical deterioration. According to the data presented here, more than $40 \%$ of patients listed as UNOS status 2 had deterioration in their clinical status. There were 2243 patients who underwent heart transplantation after initial listing as UNOS status 
TABLE 1. Sequence of heart allocation

\begin{tabular}{|c|c|c|}
\hline & Current scheme & Proposed scheme \\
\hline Local & $\begin{array}{l}\text { 1. Status } 1 \mathrm{~A} \text { patients } \\
\text { 2. Status } 1 \mathrm{~B} \text { patients } \\
\text { 3. Status } 2 \text { patients }\end{array}$ & $\begin{array}{l}\text { 1. Status } 1 \mathrm{~A} \text { patients } \\
\text { 2. Status } 1 \mathrm{~B} \text { patients }\end{array}$ \\
\hline Zone A & $\begin{array}{l}\text { 4. Status } 1 \mathrm{~A} \text { patients } \\
\text { 5. Status } 1 \mathrm{~B} \text { patients }\end{array}$ & $\begin{array}{l}\text { 3. Status } 1 \mathrm{~A} \text { patients } \\
\text { 4. Status } 1 \mathrm{~B} \text { patients }\end{array}$ \\
\hline Local & & 5. Status 2 patients \\
\hline Zone B & $\begin{array}{l}\text { 6. Status } 1 \mathrm{~A} \text { patients } \\
\text { 7. Status } 1 \mathrm{~B} \text { patients }\end{array}$ & $\begin{array}{l}\text { 6. Status 1A patients } \\
\text { 7. Status 1B patients }\end{array}$ \\
\hline Zone A & 8. Status 2 patients & 8. Status 2 patients \\
\hline Zone B & 9. Status 2 patients & 9. Status 2 patients \\
\hline Zone C & $\begin{array}{l}\text { 10. Status } 1 \mathrm{~A} \text { patients } \\
\text { 11. Status } 1 \mathrm{~B} \text { patients } \\
\text { 12. Status } 2 \text { patients }\end{array}$ & $\begin{array}{l}\text { 10. Status 1A patients } \\
\text { 11. Status 1B patients } \\
\text { 12. Status } 2 \text { patients }\end{array}$ \\
\hline Zone D & $\begin{array}{l}\text { 13. Status } 1 \mathrm{~A} \text { patients } \\
\text { 14. Status } 1 \mathrm{~B} \text { patients } \\
\text { 15. Status } 2 \text { patients }\end{array}$ & $\begin{array}{l}\text { 13. Status 1A patients } \\
\text { 14. Status 1B patients } \\
\text { 15. Status } 2 \text { patients }\end{array}$ \\
\hline
\end{tabular}

Local, Local to donor hospital; zone $A$, within 500 -mile radius of donor hospital; zone $B$, within 1000-mile radius of donor hospital; zone $C$, within 1500 -mile radius of donor hospital; zone $D$, beyond 1500 miles from donor hospital.

2, of whom 1083 (48.3\%) were upgraded in UNOS status by the time of transplantation. Furthermore, of 1265 patients who were upgraded, 87 (6.9\%) died awaiting transplantation. Although some patients who deteriorate in UNOS status may be salvaged with mechanical support, the associated morbidity and mortality with this type of procedure are not negligible. Single-center experience at Washington University corroborates these data and suggests that patients listed as UNOS status 2 continue to derive an overall benefit from transplantation. ${ }^{5}$

The proposed UNOS modification to the 1999 scheme will likely improve overall survival among patients on the heart transplant waiting list, at the expense of some patients listed as UNOS status 2 . On the basis of these data, it is ethically unjustifiable to conduct a prospective randomized trial to evaluate best medical therapy versus transplantation for patients listed as UNOS status 2. Furthermore, it may be premature to divert donor organs away from local patients listed as UNOS status 2. Until variables are identified to better stratify patients listed as UNOS status 2, caution must be exercised.

We acknowledge the efforts of the staff at UNOS for their assistance in obtaining data from the UNOS/OPTN database.
TABLE 2. Change in clinical condition for UNOS status 2 registrants 2001 to 2003

\begin{tabular}{|c|c|c|c|c|}
\hline Year & 2001 & 2002 & 2003 & Total \\
\hline \multicolumn{5}{|l|}{ Total UNOS status 2} \\
\hline registrants & 1549 & 1363 & 1272 & 4184 \\
\hline Condition improved & $85(5.5)$ & $64(4.7)$ & $27(2.1)$ & $176(4.2)$ \\
\hline \multicolumn{5}{|l|}{$\begin{array}{l}\text { deteriorated, } \\
\text { too sick to } \\
\text { undergo }\end{array}$} \\
\hline transplantation & $44(2.8)$ & $19(1.4)$ & $12(0.9)$ & $75(1.8)$ \\
\hline Medically unsuitable & $5(0.3)$ & $3(0.2)$ & $2(0.2)$ & $10(0.2)$ \\
\hline \multicolumn{5}{|l|}{ Died lawaiting } \\
\hline Total & $192(12.4)$ & $130(9.5)$ & $104(8.2)$ & $426(10.2)$ \\
\hline As status $1 \mathrm{~A}$ & $26(1.7)$ & $9(0.7)$ & $9(0.7)$ & $44(1.1)$ \\
\hline As status 1B & $18(1.2)$ & $12(0.9)$ & $13(1.0)$ & $43(1.0)$ \\
\hline As status 2 & $83(5.4)$ & $62(4.5)$ & $40(3.1)$ & $185(4.4)$ \\
\hline \multicolumn{5}{|l|}{ As temporarily } \\
\hline inactive & $65(4.2)$ & $47(3.4)$ & $42(3.3)$ & $154(3.7)$ \\
\hline \multicolumn{4}{|l|}{ Underwent } & \\
\hline Total & $876(56.6)$ & $757(55.5)$ & $610(48.0)$ & $2243(53.6)$ \\
\hline As status $1 \mathrm{~A}$ & $128(8.3)$ & $146(10.7)$ & $115(9.0)$ & $389(9.3)$ \\
\hline As status $1 \mathrm{~B}$ & $297(19.2)$ & $238(17.5)$ & $159(12.5)$ & $694(16.6)$ \\
\hline As status 2 & $451(29.1)$ & $373(27.4)$ & $336(26.4)$ & $1160(27.7)$ \\
\hline \multicolumn{5}{|l|}{ Total upgrades to } \\
\hline status $1 \mathrm{~A}$ & $160(10.3)$ & $158(11.6)$ & $131(10.3)$ & $449(10.7)$ \\
\hline \multicolumn{5}{|l|}{ Total upgrades to } \\
\hline status 1B & $336(21.7)$ & $271(19.9)$ & $209(16.4)$ & $816(19.5)$ \\
\hline
\end{tabular}

UNOS, United Network for Organ Sharing; OPTN, Organ Procurement and Transplantation Network. Based on OPTN data as of September 17, 2004. Total numbers for each year with percentages in parentheses.

\section{References}

1. Renlund DG, Taylor DO, Kfoury AG, Shaddy RS. New UNOS rules: historical background and implication for transplantation management. J Heart Lung Transplant. 1999;18:1065-70.

2. United Network for Organ Sharing. Available at: https://www.unos.org. Accessed 2005.

3. Jiminez J, Edwards LB, Higgins R, Bauerlein J, Pham S, Mallon S. Should stable UNOS Status 2 patients be transplanted? J Heart Lung Transplant. 2005;24:178-83.

4. Deng MC, DeMeester JMJ, Smits JMA, Heinecke J, Scheld HH. Effect of receiving a heart transplant: analysis of a national cohort entered on to a waiting list, stratified by heart failure severity. BMJ. 2000;321:540-5.

5. Shah NR, Ewald GA, Horstmanshof DA, Geltman EM, Moorehead SL, Moazami N. Should UNOS Status 2 patients be transplanted? J Heart Lung Transplant. 2005;24(2S):S69. 